\title{
PENINGKATAN PEMAHAMAN MASYARAKAT DESA DALEMAN TERKAIT PENATAKELOLAAN SAMPAH BERBASIS CIRCULAR ECONOMY
}

\author{
Waluyo $^{1}$, Sapto Hermawan ${ }^{2}$, Rahayu Subekti ${ }^{3}$, Wida Astuti ${ }^{4}$, Purwono SR ${ }^{5}$, Wasis Sugandha ${ }^{6}$, Pius \\ Triwahyudi ${ }^{7}$, Asianto Nugroho ${ }^{8}$ \\ 1,2,3,4,5,6,7,8 Bagian Hukum Administrasi Negara, Fakultas Hukum, Universitas Sebelas Maret, Surakarta \\ ${ }^{1}$ waluyo.fh@staff.uns.ac.id; ${ }^{2}$ saptohermawan_fh@staff.uns.ac.id; ${ }^{3}$ rahayusubekti0211@ staff.uns.ac.id; \\ ${ }^{4}$ widaastuti@staff.uns.ac.id; ${ }^{5}$ purwonosungkowo@staff.uns.ac.id; ${ }^{6}$ wasissugandha@ staff.uns.ac.id; \\ ${ }^{7}$ piustriwahyudi@staff.uns.ac.id; ${ }^{8}$ asiantonugroho@staff.uns.ac.id
}

\begin{abstract}
Abtsrak
Jumlah tonase sampah di Desa Daleman, Kecamatan Tulung, Kabupaten Klaten meningkat untuk setiap tahunnya, di mana apabila tidak dikelola dengan komprehensif dipastikan berdampak pada persoalan lingkungan, sosial, dan kesehatan. Artikel ini berusaha menjawab faktor apa saja yang menjadi hambatan dalam penerapan tata kelola sampah berbasis circular economy dan langkah-langkah strategis apa yang ditempuh para pemangku kepentingan di Desa Daleman, Kecamatan Tulung, Kabupaten Klaten guna mendukung keberhasilan tata kelola sampah berbasis circular economy. Artikel ini merupakan hasil kegiatan pengabdian yang ditulis dengan menggunakan pendekatan sosio-legal. Metode kegiatan pengabdian dilakukan dengan observasi, pendampingan, pelatihan secara terstruktur, dan evaluasi. Hasil pengabdian memaparkan bahwa hambatan dalam penerapan tata kelola sampah berbasis konsep circular economy lebih disebabkan keterbatasan lahan untuk penerapan sampling, pola pikir dan perilaku semua pemangku kepentingan, serta perbedaan persepsi tentang penerapan circular economy. Untuk itu langkah-langkah yang diperlu dilakukan adalah penguatan kelembagaan dan penyamaan pemahaman setiap pemangku kepentingan desa, dorongan peran serta masyarakat desa yang lebih aktif dan nyata, serta pengawasan dan evaluasi program.
\end{abstract}

Kata Kunci: tata kelola sampah, circular economy, sustainable goal

\section{PENDAHULUAN}

Kegiatan pengabdian ini dilatarbelakangi oleh fenomena tata kelola sampah di daerah yang sampai dengan detik ini semakin memprihatinkan. Mayoritas desa-desa di Kabupaten Klaten nampaknya kewalahan mengelola sampah yang kuantitasnya semakin bertambah untuk setiap tahun. Artikel ini menengarai bahwa salah satu pemicu tata kelola sampah yang tidak berjalan dengan baik disebabkan oleh stagnasi terobosan kebijakan desa, minimnya literasi ilmiah akan aspek ekonomi dari sampah itu sendiri, serta rendahnya partisipasi masyarakat desa dalam tata kelola sampah. Untuk itu, peran strategis dan kontribusi aktif perguruan tinggi dalam pendampingan dan advokasi penatakelolaan sampah berbasis partisipasi masyarakat diyakini mampu menjembatani antara perumusan kebijakan yang lebih adaptif terhadap isu lingkungan dengan persoalan empiris yang tengah dihadapi masyarakat. Pentingnya kolaborasi pemerintah daerah dengan perguruan tinggi merupakan rekomendasi terbaik sebagaimana dianjurkan Mahroum "policy makers should work with appropriate universities and colleges to transfer 'hands-on' expertise and training to local communities. In areas without such institutions, 
technical colleges could use similar techniques to help foster rural innovation". (Mahroum, 2007:9).

Merujuk kepada rekomendasi Mahroum tersebut, maka kegiatan pengabdian ini sekilas dapat diilustrasikan sebagai berikut,

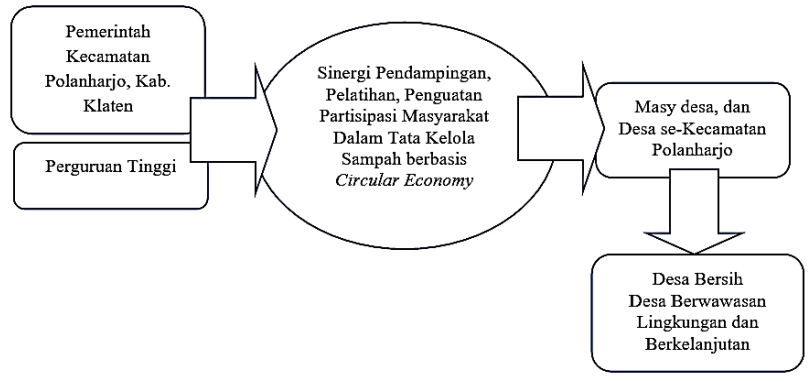

Gambar 1. Skema Kolaboratif Perguruan Tinggi dan Pemerintah Desa Daleman dalam Pengelolaan Sampah

Selaras dengan judul artikel ini, maka kolaborasi perguruan tinggi dan pemerintah daerah dalam tata kelola sampah difokuskan pada penguatan partisipasi masyarakat desa dalam mendukung tata kelola sampah berbasis circular economy. Mitra adalah masyarakat Desa Daleman, Kecamatan Tulung, Kabupaten Klaten. Analisis terhadap persoalan mitra bahwasanya di lokasi mitra pengabdian terdapat tonase sampah yang menumpuk setiap tahun. Tumpukan sampah yang berujung di Tempat Pembuangan Akhir di lokasi mitra tidak dipisahkan sedari awal, sehingga sampah masih bercampur baik sampah plastik (botol, kemasan, dll) maupun sampah aktivitas rumah tangga. Kegiatan observasi awal pada lokasi mitra ditemukan bahwa masyarakat desa daleman berikut perangkat desa belum sepenuhnya memahami tata Kelola sampah berbasis circular economy. Untuk itu, substansi artikel ini bertujuan menguraikan faktor-faktor yang menjadi hambatan dalam peningkatan pemahaman tata kelola sampah berbasis circular economy dan langkah-langkah strategis yang ditempuh melalui kegiatan pengabdian kepada masyarakat Desa Daleman, Kecamatan Tulung, Kabupaten Klaten guna mendukung keberhasilan tata kelola sampah berbasis circular economy.

\section{METODE}

Metode dalam pelaksanaan kegiatan pengabdian kepada masyarakat Desa Daleman, Kecamatan Tulung, Kabupaten Klaten dalam rangka untuk memberi pelatihan kepada masyarakat tentang peningkatan pemahaman pengelolan sampah berbasis circular economy dapat dilakukan dalam beberapa tahap. Tahap pertama adalah identifikasi persoalan. Pada tahap ini para pengabdi melakukan observasi ke lingkungan Desa Daleman, Kecamatan Tulung, Kabupaten Klaten terkait tata kelola sampah berbasis circular economy. Kegiatan observasi lapangan berlangsung selama seminggu sehingga diperoleh akar permasalahan yang ada. Tahap kedua adalah koordinasi dan konsolidasi dengan perangkat Desa Daleman, Kecamatan Tulung, Kabupaten Klaten. Tujuan dari tahap kedua ini adalah menyamakan persepsi dan mendapatkan dukungan pemerintah Desa Daleman, Kecamatan Tulung, Kabupaten Klaten dalam kerangka peningkatan pemahaman akan pengelolaan sampah berbasis circular economy. Tahap ketiga adalah sosialisasi dan pendampingan. Tahap ketiga dilaksanakan secara kontinuitas dalam kurun waktu 3 bulan. Pada tahapan ketiga dilakukan beberapa kegiatan antara lain peningkatan pemahaman konsep tata Kelola sampah berbasis circular economy, Pelatihan secara intensif mengelola sampah rumah tangga dengan menggunakan konsep circular economy, Percobaan kegiatan mengelola sampah pada Desa Daleman, Kecamatan Tulung, Kabupaten Klaten dengan menggunakan konsep circular economy. Tahap keempat adalah monitoring dan evaluasi. Kegiatan ini bertujuan untuk mengamati hambatan dan persoalan yang menyertai dalam kegiatan percobaan pengelolaan sampah berbasis circular economy. Hasil dari kegiatan tahap ke empat ini dapat digunakan sebagai data pendukung untuk memperbaiki aktivitas tata Kelola sampah berbasis circular economy yang dijalankan masyarakat Desa Daleman, Kecamatan Tulung, Kabupaten Klaten.

\section{HASIL DAN PEMBAHASAN}

\section{Hasil Observasi Tata Kelola Sampah Desa Daleman, Kecamatan Tulung, Kabupaten Klaten}

Paparan data yang diperoleh pada waktu pengabdian di Desa Daleman, Kecamatan Tulung, Kabupaten Klaten menunjukan bahwasanya landasan yuridis guna menangani persoalan sampah sejatinya telah tertuang di dalam Peraturan Daerah Kabupaten Klaten Nomor 6 Tahun 2018 tentang Penyelenggaraan Pengelolaan Sampah. Disebutkan dalam Pasal 12 angka 1 huruf b Peraturan Daerah

Lingkungan Hidup dan Kebencanaan 608 
Kabupaten Klaten Nomor 6 Tahun 2018 tentang Penyelenggaraan Pengelolaan Sampah bahwa Setiap orang berhak untuk berpartisipasi dalam setiap proses pengambilan keputusan, penyelenggaraan, dan pengawasan dalam pengelolaan sampah, di mana pelaksanaan hak sebagaimana dimaksudkan tersebut harus sejalan dengan pemenuhan kewajiban dan peran serta masyarakat. Selanjutnya, di dalam Pasal 23 ayat (2) huruf c Peraturan Daerah Kabupaten Klaten Nomor 6 Tahun 2018 tentang Penyelenggaraan Pengelolaan Sampah juga sebutkan dengan tegas bahwa Pemerintah daerah menyusun rencana pengurangan dan penanganan sampah yang dituangkan dalam rencana strategis dan rencana kerja tahunan Pemerintah Daerah, di mana rencana pengurangan dan penanganan sampah sebagaimana dimaksud sebelumnya paling sedikit memuat pola pengembangan kerjasama daerah, kemitraan, dan partisipasi masyarakat. Namun demikian pada satu sisi juga diketemukan fakta-fakta menarik, pertama, saat ini Desa Daleman, Kecamatan Tulung, Kabupaten Klaten belum mempunyai model kebijakan tata kelola sampah berbasis circular economy, baik berbentuk asistensi maupun perencanaan program. Kedua, belum tersedianya mekanisme dan bentuk keterlibatan masyarakat yang jelas terkait dengan penanganan sampah berbasis circular economy. Ketiga, belum ada langkahlangkah nyata pelibatan masyarakat dalam mengatasi persoalan sampah berbasis circular economy di Desa Daleman, Kecamatan Tulung, Kabupaten Klaten, sehingga persoalan sampah masih bertumpu kuat di tangah pemerintah kabupaten dan/atau kota.

Sebagaimana diketahui bahwasanya pendekatan circular economy merupakan sebuah konsep yang mengintegrasikan aspek ekonomis ke dalam setiap aktivitas lingkungan dalam konteks yang luas dalam kerangka pencapaian prinsip berkelanjutan dalam setiap bidang atau dalam bahasa yang sederhana diartikan sebagai pendekatan sistemik untuk pembangunan ekonomi yang dirancang untuk memberi manfaat bagi dunia usaha, masyarakat, dan lingkungan (Franco-García et al, 2019:3-10). Sebagai konsep yang digadang dapat menggantikan pola 'take-make-waste' pada linear economy, konsep circular economy dirancang ulang secara regeneratif sehingga pada akhirnya bertujuan secara bertahap untuk memisahkan angka pertumbuhan suatu daerah dari konsumsi sumber daya alam yang terbatas.
(Lacy et al, 2020: 5). Konsep circular economy bertumpu kepada tiga komponen yaitu merancang limbah dan polusi, menyimpan produk dan bahan yang digunakan, dan terakhir meregenerasi sistem secara alami. Dalam merancang limbah dan polusi, pendekatan circular economy berupaya mendesain dampak negatif dari kegiatan ekonomi yang menyebabkan kerusakan pada kesehatan manusia dan sistem alam. Termasuk dalam hal ini adalah pelepasan gas rumah kaca dan zat berbahaya, pencemaran udara, tanah, dan air. Dalam menggunakan bahan atau sumber daya alam, circular economy mendukung aktivitas yang melestarikan nilai-nilai keberlanjutan dalam bentuk penghematan energi, berpihak pada aspek tenaga kerja, dan meminimalisir material yang tidak dapat didaur ulang. Ini berarti merancang untuk ketahanan, penggunaan kembali, produksi ulang, dan daur ulang untuk menjaga produk, komponen, dan bahan tetap beredar dalam perekonomian. Pilar terakhir, dalam meregenerasi sistem secara alami pendekatan circular economy semaksimal mungkin menghindari penggunaan sumber daya alam tak terbarukan serta melestarikan atau mendorong pemanfaatan sumber daya alam yang terbarukan, misalnya dengan mengembalikan nutrisi berharga ke tanah untuk mendukung regenerasi, atau menggunakan energi terbarukan sebagai lawan aktivitas yang mengandalkan bahan bakar fosil.

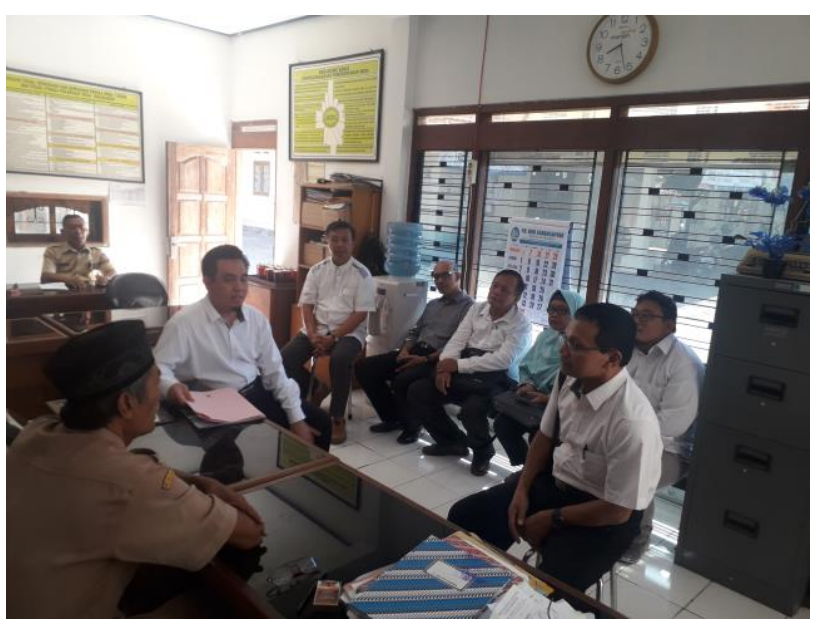

Gambar 1. Proses Perijinan di Desa Daleman, Kecamatan Tulung, Kabupaten Klaten

Terkait dengan hasil kegiatan observasi pada lokas mitra pengabdian, diperoleh fakta empiris beberapa faktor yang menjadi kendala pengelolaan

Lingkungan Hidup dan Kebencanaan 
sampah di Desa Daleman, Kecamatan Tulung, Kabupaten Klaten belum mengarah kepada tata kelola berbasis circular economy, antara lain: Pertama, rendahnya pola pikir, gaya hidup, serta perilaku seluruh pemangku kepentingan Desa Daleman, Kecamatan Tulung, Kabupaten Klaten. Selama ini aktivitas publik, pemangku kebijakan dan para pelaku ekonomi terlena dengan pendekatan linear economy, sehingga semua limbah barang konsumsi termasuk residu aktivitas sehari-hari berakhir di Tempat Pembuangan Akhir (TPA). Akumulasi jumlah tonase sampah yang dihasilkan setiap tahun ternyata tidak sebanding dengan jumlah personil yang mengelola sampah, di mana pada akhirnya tumpukan sampah yang ada tidak dapat dikelola dengan baik. Sampah yang tidak terkelola dengan optimal secara tidak langsung berdampak kepada persoalan kesehatan, sosial, dan lingkungan.

Hambatan kedua, adalah limitasi persepsi tentang penerapan circular economy. Selama ini persepsi tentang circular economy tergantung pada persoalan hilir semata, sehingga kebijakan pemerintah desa difokuskan kepada bagaimana memilah dan mengolah sampah yang sudah menumpuk untuk kemudian dijadikan barang yang bernilai ekonomis. Sementara jika merujuk pada teori yang ada, proses dan mekanisme circular economy dimulai dari hulu sampai ke hilir. Artinya proses produksi atau siklus manufaktur sudah sejak awal mengubah mind set mereka bahwa barang yang akan diproduksi tidak akan merusak lingkungan, tahan lama, dan dapat dimanfaatkan kembali secara ekonomis (Malets et al, 2018:23). Pada titik ini, transisi perubahan pola pikir dan pergeseran paradigma industri di kalangan swasta sangat dibutuhkan. Sementara pada sisi yang bersamaan, peran pemerintah adalah memberikan pedoman, arahan, dan bimbingan melalui program-program dan/atau kebijakan yang mengarahkan kepada pelaku industri untuk segera mengubah budaya kerja yang mereka jalankan selama ini. Pemerintah daerah harus berani mengambil terobosan kebijakan untuk 'memaksa' para pelaku industri agar segera bergegas meningggalkan zona nyaman yaitu linear economy.

Hambatan terakhir adalah keterbatasan lahan di Desa Daleman, Kecamatan Tulung, Kabupaten Klaten untuk penerapan sampling program circular economy. Mendasarkan kepada hasil pengabdian, beberapa perusahaan di Kabupaten Klaten sudah bersedia untuk menerapkan (tahap awal) konsep circular economy, dalam arti membuka diri untuk menginternalisasi proses-proses manufaktur yang membawa kepada perubahan material dan produk yang dihasilkan agar lebih ramah lingkungan dan berkelanjutan. Namun demikian, proses ini tentunya membutuhkan kapital yang tidak sedikit, terutama lahan untuk dijadikan percontohan penerapan circular economy. Proses migrasi dan transformasi perusahaan dari linier economy ke circular economy juga membutuhkan sumber daya manusia yang teruji dan terukur, hal ini tentunya juga hal yang tidak mudah. Disinilah letak pemerintah desa untuk mendorong agar jalin kelindan kerjasama dengan masyarakat dan perguruan tinggi lebih dikuatkan lagi. Pemerintah desa melalui program dan kebijakan yang terfokus seyogyanya dapat meningkatkan peran serta masyarakat sekitar, seperti misalnya kerjasama pemanfaatan lahan dengan meletakan perhitungan ekonomi yang saling menguntungkan dapat dikomunikasikan antara pengusaha dengan publik dengan cara yang elok.

\section{Langkah-Langkah yang Ditempuh Guna Mendukung Keberhasilan Tata Kelola Sampah Berbasis Circular Economy di Desa Daleman, Kecamatan Tulung, Kabupaten Klaten}

Setelah mencermati beberapa hambatan atau kendala yang dihadapi, artikel ini menguraikan beberapa langkah-langkah pengabdian yang sudah ditempuh guna mendukung keberhasilan penerapan tata kelola sampah berbasis circular economy di Desa Daleman, Kecamatan Tulung, Kabupaten Klaten ke depan. Langkah-langkah tersebut antara lain, Pertama adalah pelatihan penguatan kelembagaan dan penyamaan persepsi setiap pemangku kepentingan terhadap tata kelola sampah berbasis circular economy. Pemerintah desa dengan segala asset dan fasilitas yang dipunyai memiliki kemampuan lebih untuk terlibat dengan berbagai pemangku kepentingan dari berbagai sektor dan mengkatalisasi tindakan yang akan diambil (Hartley et al, 2020: 104634). Kegiatan pelatihan ini memfokuskan bahwa salah satu kunci keberhasilan circular economy terletak pada harmonisasi pemahaman, kolaborasi, dan tindakan di dalam dan antar sektor. Pemerintah desa dapat menggunakan dukungan finansial untuk membantu memupuk

Lingkungan Hidup dan Kebencanaan $\quad 610$ 
inovasi dan pembentukan pasar yang prolingkungan, sementara tindakan fiskal seperti pajak, denda, dan biaya, dapat digunakan untuk memberi insentif kepada perusahaan yang bermigrasi ke arah circular economy atau mencegah perilaku industri yang tidak sejalan dengan konsep pembangunan berkelanjutan.

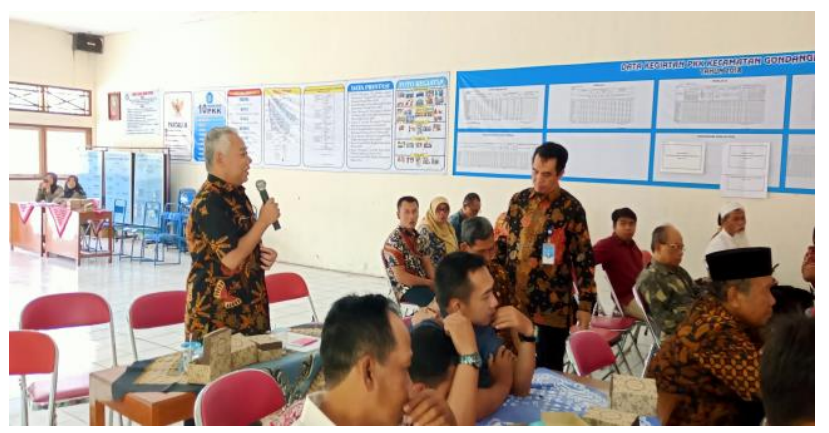

Gambar 2. Kegiatan Pelatihan

Realisasi nyata kegiatan pelatihan penguatan kelembagaan dan penyamaan persepsi berupa peta jalan (roadmap) yang telah disepakati. Kendatipun tidak ada satupun ramuan mujarab terkait kebijakan circular economy, namun substansi roadmap tata kelola sampah setidaknya memuat: kebijakan proses produksi dan desain produk yang berpihak kepada keberlanjutan lingkungan; penentuan standar proses produksi berbasiskan pendekatan circular economy; diseminasi informasi seputar roadmap kepada setiap pemangku kepentingan berikut dengan kepastian penentuan tenggat waktu penerapannya; pemberian insentif finansial kepada pelaku industri yang menunjukan itikad baik (good will) untuk memulai menginfiltrasikan pendekatan circular economy ke dalam setiap denyut aktivitas bisnisnya; pemberian dukungan fasilitas kebijakan dan pendampingan atau asistensi secara terukur dan berkesinambungan; membuat kawasan percontohan terkait dengan pelaksanaan tata kelola sampah berbasis circular economy yang didukung penuh oleh kebijakan pemerintah daerah. Dampak dari kegiatan ini masyarakat Desa Daleman, Kecamatan Tulung, Kabupaten Klaten sudah mulai memahami tata Kelola sampah berbasis circular economy. Kendatipun sifatnya masih permulaan namun antusisme untuk menjalankan tata Kelola ini sangat positif.

Langkah strategis kedua adalah peningkatan pemahamaman melalui workshop dan pelatihan peran serta masyarakat yang lebih aktif dan nyata. Melalui budaya hukum yang melekat pada akar historis masyarakat, beberapa ahli sosiologi hukum memberikan penekanan bahwa nilai-nilai dan sikap masyarakat-lah yang akan menentukan struktur hukum apa yang hendak digunakan dan mengapa struktur hukum tersebut yang dipilih oleh masyarakat serta aturan mana yang berfungsi dan mana yang tidak, dan mengapa aturan-aturan tersebut tidak berlaku. Dalam kedudukannya sebagai aspek prinsipil dan terikat kuat dengan aspek lain secara kolektif (substansi hukum dan struktur hukum), aspek budaya hukum berkontribusi vital dalam menentukan efektivitas keberlakuan hukum pada suatu daerah, sehingga secara vice versa dapat dikatakan bahwasanya antusiasme respon publik atas persoalan-persoalan hukum yang menjadi isu di masyarakat akan menentukan prioritas pembentukan hukum dan efektivitas hukum yang berjalan. Poin sentral dari kajian budaya hukum tidak dapat dilepaskan dari pembahasan mengenai peran bermakna partisipasi publik terhadap pembentukan hukum serta kepatuhan publik terhadap hukum yang berlaku (Smol et al, 2020:4578).

Substansi workshop dan pelatihan peran serta masyarakat disesuaikan dengan pendapat Creighton bahwasanya partisipasi publik dapat diberikan pengertian sebagai sebuah proses komunikasi dan interaksi dua arah, di mana persoalan yang menjadi perhatian, kepentingan serta nilai-nilai dari masyarakat wajib diintegrasikan ke dalam perumusan setiap produk hukum pemerintahan dengan tujuan mencapai keputusan yang lebih baik serta didukung oleh seluruh komponen masyarakat (Creighton, 2005:7). Mendasarkan kepada pengertian tersebut maka pokok-pokok pikiran ideal yang dapat diambil dari aktivitas partisipasi publik yaitu pertama, partisipasi publik berlandaskan kepada sebuah keyakinan bahwa siapapun memiliki hak untuk terlibat proses perumusan produk hukum, terlebih kepada siapapun yang terkena dampak atau imbas dari produk hukum yang dikeluarkan oleh pemerintah. Kedua, partisipasi publik mencakup sebuah kesanggupan atau janji bahwa kontribusi gagasan dan ide tentang persoalan yang berasal dari setiap anggota masyarakat dapat mempengaruhi produk hukum yang dikeluarkan. Ketiga, partisipasi publik mempromosikan dan mendukung produk hukum yang berkelanjutan dengan mengakui dan Lingkungan Hidup dan Kebencanaan

611 
mengkomunikasikan setiap kehendak dan kepentingan semua masyarakat, termasuk di dalamnya keinginan dan kepentingan dari pengambil keputusan secara berimbang. Keempat, partisipasi publik mencari masukan-masukan dari seluruh elemen masyarakat dalam rangka mendesaian atau merancang suatu mekanisme ideal tentang bagaimana setiap masyarakat dapat ikut terlibat dalam proses dan evaluasi setiap produk hukum. Kelima, partisipasi publik menyediakan informasi objektif dan/atau pengetahuan yang cukup memadai tentang persoalan yang sedang dihadapi kepada seluruh masyarakat supaya keterlibatan masyakarat dapat dilaksanakan dengan berarti dan penuh makna. Terakhir, partisipasi publik menyediakan ruang diskusi secara intensif antar anggota masyarakat guna mendiskusikan keinginan dan kepentingan dari seluruh elemen masyarakat supaya produk hukum dapat dijalankan dengan baik.

Substansi workshop dan pelatihan menegaskan bahwa Partisipasi publik merupakan konsep yang dinamis dan tidak dapat digeneralisasi untuk satu persoalan satu dengan yang lain. Untuk itu, partisipasi pubik harus diberikan penjelasan menyeluruh dan pemahaman memadai guna mengoptimalkan peran keterlibatan masyarakat dalam kerangka memperoleh tujuan yang diharapkan. Bertalian dengan konsep partisipasi, Rowe dan Frewer (Rowe and Frewer, 2005:262) kemudian mengklasifikasikan mekanisme keterlibatan publik menjadi tiga kelompok. Pertama adalah komunikasi publik (public communication), di mana melalui komunikasi publik pihak sponsor atau penyelenggara kegiatan berusaha memaksimalkan pemindahan informasi yang relevan serta secara efisien meminimalisasi hilangnya informasi kepada jumlah maksimum populasi terpilih melalui pemrosesan informasi yang efisien oleh penerima (dalam hal ini publik/masyarakat). Kedua adalah konsultasi publik (public consultation), di mana aktivitas ini berusaha memaksimalkan informasi yang relevan dari jumlah maksimum populasi terpilih dan memindahkannya secara efisien dengan indikator hilangnya informasi seminimal mungkin kepada pihak penyelenggara kegiatan, serta dilakukan dengan pemrosesan informasi yang efisien oleh penerima pihak sponsor atau penyelenggara kegiatan. Ketiga adalah partisipasi publik (public participation), di mana aktivitas ini berupaya memaksimalkan informasi yang relevan dari jumlah maksimum semua sumber yang relevan dan mentransfernya (dengan indikator hilangnya informasi secara minimal) kepada pihak lain, serta melalui mekanisme pemrosesan informasi yang efisien oleh penerima (baik pihak pemerintah sebagai sponsor maupun masyarakat) sehingga penggabungannya menjadi komposisi dua arah yang akurat.

Terkait dengan keterlibatan publik dalam tata kelola sampah berbasis circular economy, desain partisipasi publik yang berkualitas guna mengatasi persoalan ketidakoptimalan penerapan circular economy di Desa Daleman, Kecamatan Tulung, Kabupaten Klaten dilakukan melalui pelatihan penentuan kriteria untuk evaluasi partisipasi publik yang efektif, di mana terdiri dari dua komponen penting yaitu pertama, kriteria penerimaan, di mana menyangkut fitur dari suatu metode yang membuat informasi tentang tata kelola sampah berbasis circular economy dapat diterima dengan baik oleh publik yang lebih luas melalui konstruksi yang efektif. Kedua adalah kriteria proses, di mana menyangkut fitur dari desain proses partisipasi yang bertanggung jawab guna memastikan bahwa proses perpindahan informasi tentang tata kelola sampah berbasis circular economy terjadi dengan cara yang efektif. Bertalian dengan kriteria penerimaan (acceptance criteria) di dalam pemindahan informasi tata kelola sampah berbasis circular economy dari pihak sponsor (pihak pemerintah, pihak pelaku industri) kepada publik maka perlu memperhatikan indikator-indikator yaitu: Kriteria keterwakilan. Para peserta publik harus terdiri dari sampel yang representatif dari populasi masyarakat yang terkena dampak dari tata kelola sampah yang buruk. Salah satu perhatian yang sering diungkapkan melalui literatur yang ada adalah perlunya peserta untuk menjadi perwakilan dari masyarakat yang lebih luas atau sub-kelompok yang terpengaruh dalam populasi, daripada hanya mewakili beberapa kelompok yang dipilih sendiri oleh pihak sponsor. Kriteria independensi, di mana proses pemindahan informasi terkait tata kelola sampah berbasis circular economy harus dilakukan dengan cara yang independen dan tidak boleh bias, sehingga semua pihak yang terlibat tidak hanya independen dalam aktualitas akan tetapi harus terlihat independen di dalam proses proses pemindahan informasi terkait 
tata kelola sampah berbasis circular economy. Di sini perlu ditegaskan juga bahwasanya perwakilan dari masyarakat harus independen dari afiliasi apapun ke pihak sponsor. Independensi mungkin diperoleh dan ditunjukkan melalui penunjukan komite pengarah atau tim manajemen yang menggabungkan anggota dari beragam badan atau organisasi netral, seperti pelibatan akademisi dari perguruan tinggi. Selanjutnya adalah kriteria keterlibatan secara dini. Dalam kriteria ini, publik harus dilibatkan sedini mungkin dalam proses pemindahan informasi terkait tata kelola sampah berbasis circular economy, terutama dalam tahapan literasi dan persepsi. Kriteria pengaruh. Keluaran prosedur pemindahan informasi terkait tata kelola sampah berbasis circular economy wajib memiliki dampak atau imbas yang nyata terhadap produk hukum dan/atau kebijakan yang digulirkan, sehingga melalui kriteria ini dampak yang nyata terhadap produk hukum dan/atau kebijakan dapat terlihat dengan terukur dan jelas untuk kemudian jika ditemukan sesuatu yang kurang dilakukan pembenahan seperlunya. Kriteria transparansi, di mana proses pemindahan informasi terkait tata kelola sampah berbasis circular economy harus transparan sehingga publik dapat melihat apa yang sedang terjadi dan bagaimana produk hukum dan/atau kebijakan dirumuskan. Melalui proses transparan, kemungkinan kecurigaan publik tentang adanya motif negatif dari pihak sponsor dapat dihindari.

Selanjutnya, selain indikator di dalam kriteria penerimaan (acceptance criteria) perlu juga diperhatikan terkait indikator-indikator yang terdapat dalam kriteria proses (process criteria) dalam rangka merumuskan desain evaluasi partisipasi publik yang efektif dan efisien. Indikatorindikator dalam kriteria proses (process criteria) antara lain adalah: Kriteria aksesibilitas terhadap sumber informasi. Kriteria ini mensyaratkan bahwasanya semua pihak baik sponsor maupun publik harus memiliki kemudahan akses terhadap pengetahuan yang cukup dan informasi yang memadai terkait produk hukum dan/atau kebijakan tata kelola sampah berbasis circular economy yang hendak diimplementasikan. Kriteria definisi tugas. Kriteria ini mensyaratkan bahwasanya sifat dan ruang lingkup dari cakupan partisipasi harus didefinisikan dengan jelas. Hal ini penting dilakukan untuk memastikan bahwa semua pihak tidak terdapat kebingungan dan perselisihan terkait dengan ruang lingkup partisipasi, luaran yang diharapkan, dan mekanisme prosedur. Setiap tahapan dalam aspek ini harus didefinisikan dengan jelas pada tahap permulaan, sehingga kemungkinan perselisihan yang disebabkan oleh kesalahpahaman dari salah satu pihak dapat diminimalisasi. Kriteria pengambilan keputusan secara terstruktur, di mana pada kriteria ini, proses partisipasi publik wajib menggunakan serta menyediakan mekanisme yang tepat guna menyusun dan menampilkan proses pengambilan keputusan yang merepresentasikan keinginan kedua belah pihak secara berimbang. Untuk itu, melalui pelatihan pengambilan keputusan dalam hal pemanfaatan tata kelola sampah berbasis circular economy secara terstruktur dan secara berkesinambungan mutlak dibutuhkan dengan tujuan memberikan latihan-latihan bagaimana mekanisme yang berjalan di dalam proses partisipasi guna memberikan keyakinan bahwa peserta mekanisme dapat tepat, cermat, dan terukur dalam rangka menyusun serta menampilkan proses pengambilan keputusan. Kriteria efektivitas biaya, kriteria ini memberikan penjelasan bahwasanya prosedur partisipasi publik seharusnya efektif dalam pembiayaan. Tidak dipungkiri bahwa persoalan biaya merupakan perhatian utama bagi para pihak yang terlibat dalam mengorganisir sebuah desain partisipasi publik. Untuk itu, dalam kerangka mengoptimalkan tata kelola sampah berbasis circular economy pada publik maka mekanisme pembiayaan dalam proses partisipasi dapat dibebankan kepada pihak sponsor secara bergantian (dalam hal ini secara bergiliran baik pihak pemerintah, pihak industri). Dampak dari kegiatan kedua ini masyarakat Desa Daleman, Kecamatan Tulung, Kabupaten Klaten sudah mulai melaksanakan tata Kelola berbasis circular economy. Kendatipun belum seluruhnya, namun perwakilan 5 rumah tangga per RT dari seluruh RT di Desa Daleman, Kecamatan Tulung, Kabupaten Klaten akan menyulut semangat RT yang lain untuk menjalankan kegiatan tata Kelola sampah berbasis model circular economy.

Setelah pelatihan dan workshop tentang penguatan kelembagaan, penyamaan persepsi maupun literasi, serta mendorong keterlibatan publik secara aktif, maka langkah strategis ketiga atau

Lingkungan Hidup dan Kebencanaan

613 
selanjutnya adalah pelatihan dan workshop pengawasan dan evaluasi program. Pengawasan dan evaluasi program merupakan suatu proses untuk menilai seberapa jauh suatu program dapat berhasil dijalankan, yaitu dengan membandingkan antara hasil yang diperoleh dengan tujuan dan/atau target program yang ditentukan. Dalam bahasa yang lebih sederhana pengawasan dan evaluasi adalah aktivitas yang bertujuan untuk menilai kemanfaatan suatu program apakah berdampak positif atau negatif., sehingga pengawasan dan evaluasi program dapat dikatakan sebagai aktivitas yang berkesinambungan menyangkut estimasi atau penilaian program yang menyangkut substansi, implementasi, dan dampak. Dalam kerangka menuju keberhasilan penerapan tata kelola sampah berbasis circular economy, maka kegiatan pengawasan dan evaluasi dapat dilakukan secara bertahap sehingga dari masing-masing tahap dapat diketahui tingkat keberhasilannya. Jika ada kendala terhadap program pada masing-masing tahapan maka dapat segera dievaluasi dan diperbaiki untuk mendapatkan manfaat dan dampak yang optimal.

\section{KESIMPULAN}

Tawaran penggunaan tata kelola sampah berbasis pendekatan circular economy di Desa Daleman, Kecamatan Tulung, Kabupaten Klaten merupakan salah satu terobosan kebijakan yang seyogyanya dapat diimplementasikan dengan mengingat jumlah kuantitas sampah yang semakin menumpuk untuk setiap tahunnya. Artikel ini menyimpulkan bahwa tata kelola sampah berbasis pendekatan circular economy di Desa Daleman, Kecamatan Tulung, Kabupaten Klaten belum berjalan dengan maksimal karena disebabkan oleh beberapa hambatan. Artikel ini kemudian menawarkan solusi supaya pelatihan, workshop, dan pendampingan tata kelola sampah berbasis pendekatan circular economy di Desa Daleman, Kecamatan Tulung, Kabupaten Klaten melalui kegiatana pelatihan dan workshop penguatan kelembagaan, penyamaan pemahaman atau persepsi setiap pemangku kepentingan, dorongan peran serta masyarakat yang lebih aktif dan nyata, serta pengawasan dan evaluasi program. Apabila tata kelola sampah berbasis pendekatan circular economy di Desa Daleman, Kecamatan Tulung, Kabupaten Klaten dijalankan dengan baik dan terukur, maka artikel ini berpendapat bahwa isu dan persoalan sampah dapat diselesaikan dengan baik untuk tahun mendatang.

\section{UCAPAN TERIMAKASIH}

Ucapan terimakasih disampaikan kepada Universitas Sebelas Maret Surakarta melalui Lembaga Penelitian dan Pengabdian Masyarakat yang telah mendanai kegiatan pengabdian tahun 2020.

\section{REFERENSI}

Creighton, James L. (2005). The Public Participation Handbook: Making Better Decisions Through Citizen Involvement, San Francisco: Wiley \& Sons.

Franco-García, María-Laura, Jorge Carlos Carpio-Aguilar, Hans Bressers. (2019). Towards Zero Waste, Circular Economy Boost: Waste to Resources. Switzerland: Springer Nature.

Hartley, Kris, Ralf van Santen, Julian Kirchherr.(2020). Policies for transitioning towards a circular economy: Expectations from the European Union (EU), Resources, Conservation \& Recycling 155: 104634.

Lacy, Peter, Jessica Long, Wesley Spindler. (2020). The Circular Economy Handbook: Realizing the Circular Advantage, London: Palgrave Macmillan.

Mahroum, Sami. (2007). Rural Innovation. London: Nesta.

Maletz, Roman, Christina Dornack, Lou Ziyang. (2018). Source Separation and Recycling: Implementation and Benefits for a Circular Economy, Switzerland: Springer International Publishing.

Smol, Marzena, Joanna Duda, Agnieszka Czaplicka-Kotas, Dominika Szołdrowska. (2020). Transformation towards Circular Economy (CE) in Municipal Waste Management System: Model Solutions for Poland, Journals Sustainability 12 (11): 4561.

Punch, Keith F. (2000). Developing Lingkungan Hidup dan Kebencanaan 614 
Effective Research Proposals Essential Resources for Social Research, London: Sage Publications.

Rowe, Gene Lynn Jayne Frewer. (2005). A
Typology of Public Engagement Mechanisms, Science, Technology, \& Human Values 30 (2):216-7 